\title{
Angelo Miele
}

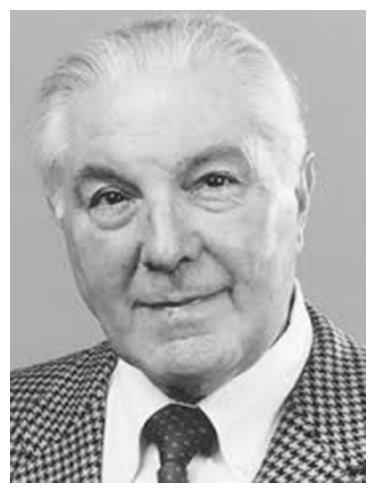

Founding Editor Miele Died in March

On March 19, 2016, Angelo Miele, a pioneer in the development and application of methods for the optimization of aerospace vehicle trajectories, died at the age of 93. In 1967, Miele founded the Journal of Optimization Theory and Applications. He retired from the journal at the end of 2009, having been its editor for 43 years. He always attributed the success of the journal to his dedicated Associate Editors.

Miele was born in Formia, Latina, Italy in 1922. He spent most of his career in academia, where he was an excellent teacher and researcher. He was truly an inspiration to his students, both past and present.

Although Miele spent most of his life in the United States, becoming a citizen in 1985, his heart never really left Italy. He visited Italy often, and he requested that his ashes be returned to Formia, his birthplace, for burial. 